\title{
Asessment of Serum Procalcitonin Level in Patients with Chronic Obstructive Pulmonary Disease
}

\author{
S.A.Issa ${ }^{1}$, M.A.Elmahdy ${ }^{1}$, O.S.EIShimi ${ }^{2}$, M.E.EINaggar ${ }^{1}$ and M.M.Behairy ${ }^{1}$ \\ ${ }^{1}$ Chest Diseases, Dept., Faculty of Medicine, Benha Univ., Benha, Egypt \\ ${ }^{2}$ Clinical and Chemical Pathology, Dept., Faculty of Medicine, Benha Univ., Benha, Egypt \\ E-Mail:mahabehairy89@gmail.com
}

\begin{abstract}
Chronic Obstructive Pulmonary Disease (COPD) is currently one of the leading causes of mortality in the globe, according to the World Health Organization. When COPD sufferers have an acute exacerbation, the infectiondetecting hormone procalcitonin (PCT) may be administered (AECOPD). The development of COPD is linked to PCT and other viral inflammatory variables. The goal of this research was to determine the PCT level in patients with COPD. Methods: ELISA was used to monitor PCT levels throughout AECOPD and after the patient was stabilised. Study groups differed significantly in PCT results (P-value 0.001). Stable (2220.9 pg/ml) and exacerbation (2679 $\mathrm{pg} / \mathrm{ml}$ ) groups had higher levels, whereas the control group had considerably lower levels (1696.9 pg/ml). Compared to the control group $(2220.9 \mathrm{pg} / \mathrm{ml})$, it was considerably greater in the exacerbation group (2679 pg/ml). Conclusion: In patients with stable COPD and AECOPD, PCT has a negative relationship with severity.
\end{abstract}

Key words: COPD, AECOPD, Procalcitonin.

\section{Introduction}

It is currently the third leading cause of mortality in the world, and 90 percent of these fatalities occur in low and middle-income countries (LMICs). COPD claimed the lives of more than 3 million individuals in 2012, or 6 percent of all fatalities worldwide. In terms of public health, COPD is a significant issue that can be both prevented and treated [1].

Chronic obstructive pulmonary disease (COPD), a prevalent, curable, and preventive condition, is defined by airway and/or alveolar abnormalities that are generally induced by extensive exposure to noxious particles or gases and affected by host factors, including faulty lung development [1].

It is described as an abrupt exacerbation of respiratory symptoms that need extra treatment.

A patient's health, hospitalisation and readmission rates, and disease progression are all adversely affected by COPD exacerbations [1].

Calcitonin is synthesised from the peptide precursor procalcitonin (PCT). The thyroid's parafollicular cells ( $\mathrm{C}$ cells) and the neuroendocrine cells of the lung and gut synthesise it, and it contains 116 amino acids [2].

Procalcitonin levels in the bloodstream of healthy people fall below the clinical test detection limit of $0.01 \mathrm{~g} / \mathrm{L}$. When the body is exposed to a proinflammatory stimuli, such as a bacterial infection, the amount of procalcitonin increases. Consequently, it is often referred to as an acute phase reactant. ' In this situation, the cells of the lungs and the gut are the primary producers. Non-infectious inflammations do not cause a considerable increase in it. Blood levels of procalcitonin may reach to $100 \mathrm{~g} / \mathrm{L}$ in the event of a severe infection with an accompanying systemic reaction. The half-life of procalcitonin in serum is between 25 and 30 hours. An interesting fact about infection-induced procalcitonin elevations is the lack of an accompanying rise in calcitonin or fall in blood calcium levels [3].

PCT, an acute phase inflammatory protein that has been used as a biomarker for bacterial infections for the last two decades, is linked to widespread and severe infections and does not rise in viral infections, autoimmune illnesses, or bacterial colonisation. PCT levels in typical persons range from $0.1 \mathrm{ng} / \mathrm{ml}$ to 0.2 $\mathrm{ng} / \mathrm{ml}$. Healthy volunteers in previous research had a rise in PCT levels 2 hours after receiving bacterial endotoxin, which peaked 12 hours later. There is a 12 hour plateau, and then a 20-24-hour decline. When infected, PCT responds quickly. [4]

During AECOPD, procalcitonin (PCT) has been employed as an infection indication. PCT and other viral inflammatory variables are linked to the evolution of COPD, however PCT's prognostic significance in COPD is comparatively little studied [5].

\section{Aim of the work}

This study aimed to assess procalcitonin level in COPD patients

\section{Subjects and Methods}

This prospective case-control study was conducted at Chest Diseases department, Benha University Hospital in the period between January 2021 to Mars 2021.

Inclusion criteria

COPD patients are diagnosed according to Global initiative for Chronic Obstructive Pulmonary Disease. (1)

Stable COPD patients were diagnosed according to GOLD (2021) with:

- Symptoms of chronic cough, sputum production, dyspnea \& or a history of exposure to risk factor of the disease.

- The presence of post bronchodilator FEV1/FVC $<70 \%$. 
Stable COPD patients divided according to post bronchodilator FEV1\% predicted value :

- Mild : FEV $1 \geq 80 \%$ predicted

- Moderate : $50 \% \leq \mathrm{FEV} 1<80 \%$ predicted

- Severe : $30 \% \leq \mathrm{FEV} 1<50 \%$ predicted

- Very severe : FEV1 $<30 \%$ predicted

- COPD exacerbation defined as sudden change in the usual symptoms (dyspnea, cough or expectoration) beyond daily variation that necessitate change in regular medication.
Methods:

All subjects were subjected to the following:

- Through history taking \&clinical examination:

- Plain chest $\mathrm{x}$ - ray ( postero-anterior view) \& ( left lateral view)

- Pulmonary function test( spirometry) before \& after bronchodilator

- Laboratory investigations included:

Complete blood picture (CBC)

Erethrocyte sedimentation rate (ESR)

Renal function test: serum creatinine, blood urea Liver function test: Serum aspartate and alanine aminotransferases (AST and ALT), serum albumin Assay for Serum PCT level using ELISA technique

\section{Results}

Table (1) Comparison of studied groups regarding age, sex, BMI, and SI

\begin{tabular}{|c|c|c|c|c|c|c|c|c|c|}
\hline \multirow{2}{*}{\multicolumn{2}{|c|}{ Variable }} & \multicolumn{6}{|c|}{ COPD in } & \multirow[t]{2}{*}{ Test } & \multirow[t]{2}{*}{$\mathbf{P}$} \\
\hline & & $\begin{array}{r}\text { St } \\
\text { COPI }\end{array}$ & $=30$ ) & $\begin{array}{l}\text { Exac } \\
\text { grou] }\end{array}$ & $\begin{array}{l}\text { ation } \\
\mathbf{1}=30 \text { ) }\end{array}$ & $\begin{array}{r}\text { Cont } \\
(\mathbf{I}\end{array}$ & ) & & \\
\hline \multirow[t]{2}{*}{ Age (ys) } & Mean \pm SD & & & & 1.3 & \multicolumn{2}{|c|}{$58 \pm 7.7$} & $\begin{array}{c}\text { ANOVA }= \\
1.84\end{array}$ & $\begin{array}{l}\text { 0.16 } \\
\text { (NS) }\end{array}$ \\
\hline & Range & \multicolumn{2}{|c|}{$42-77$} & & & \multicolumn{2}{|c|}{$40-69$} & & \\
\hline BMI & Mean \pm SD & \multicolumn{2}{|c|}{$22.8 \pm 3.2$} & \multicolumn{2}{|c|}{$23.6 \pm 2.4$} & \multicolumn{2}{|c|}{$24.3 \pm 2.1$} & & $0.05(\mathrm{NS})$ \\
\hline \multirow{3}{*}{$\begin{array}{l}\text { No of smoked } \\
\text { cigarettes /year }\end{array}$} & Mean \pm SD & \multicolumn{2}{|c|}{$935 \pm 259.6$} & \multicolumn{2}{|c|}{$980.0 \pm 165.6$} & & $t=0.59$ & 0.560 \\
\hline & Range & \multicolumn{2}{|c|}{$600-1200$} & \multicolumn{2}{|c|}{$600-1200$} & \multicolumn{2}{|c|}{ - } & & \\
\hline & & No. & $\%$ & No. & $\%$ & No. & $\%$ & $\chi^{2}$ & \\
\hline \multirow[t]{2}{*}{ Sex } & Males & 25 & 83.3 & 22 & 73.3 & 13 & 65.0 & 2.22 & 0.33 \\
\hline & Females & 5 & 16.7 & 8 & 26.7 & 7 & 35.0 & & (NS) \\
\hline
\end{tabular}

there were no significant differences between the three studied groups regarding age, BMI, gender and smoking. in Stable group the mean age was 59.7 \pm 9.3 years ranging from 42 to 77 years, in exacerbation group the mean age was $63.2 \pm 11.3$ years ranging from 39 to 85 years, in control group the mean age was $58 \pm 7.7$ years ranging from 40 to 69 years $(\mathrm{P}$-value $=0.16)$. Most of patients were males: 25 in stable group $(83.3 \%), 22$ in exacerbation group $(73.3 \%)$ and $13(65.0 \%)$ in control group $(65.0 \%)$ (P-value $=0.33)$, and SI was higher in exacerbated group $(980.0 \pm 165.6)$.

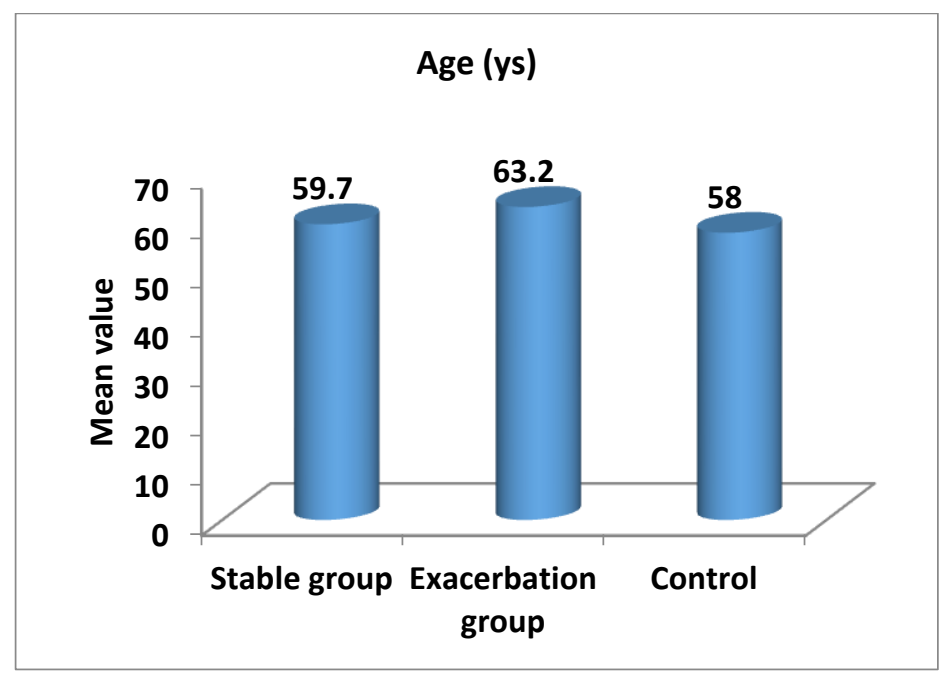

Fig. (1) Bar chart showing the mean age among the studied groups. 


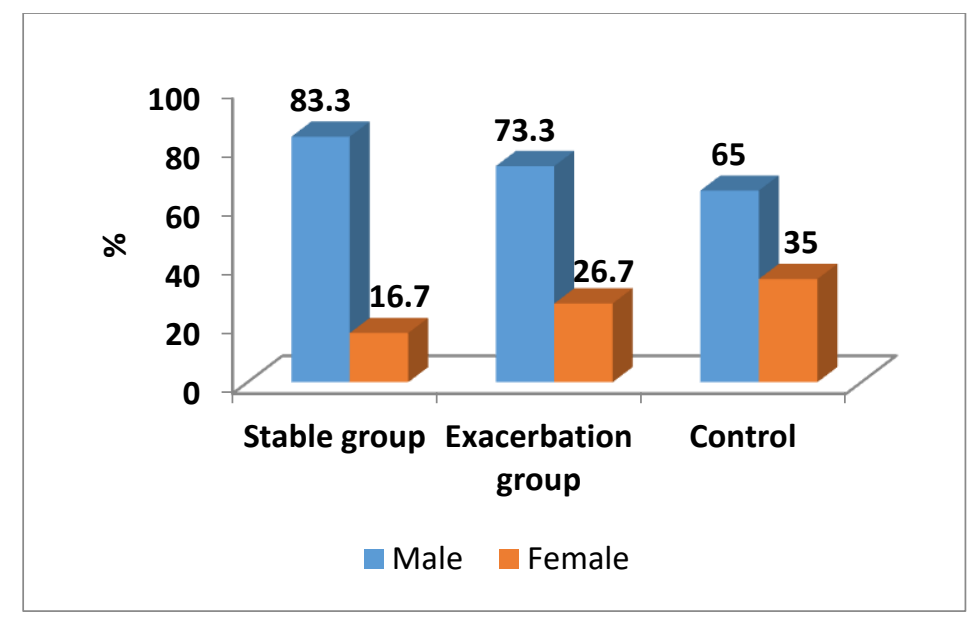

Fig. (2) Bar chart showing the gender distribution among the studied groups

Table (2) Comparing the studied groups regarding serum, procalcitonin level.

\begin{tabular}{|c|c|c|c|c|c|c|c|c|c|c|}
\hline \multirow[t]{2}{*}{ Variable } & \multicolumn{3}{|c|}{ Stable group $(n=30)$} & \multicolumn{3}{|c|}{ Exacerbation group $(\mathrm{n}=30)$} & \multicolumn{3}{|c|}{ Control group $(n=20)$} & \multirow{2}{*}{$\begin{array}{c}\text { KW } \\
(\mathbf{P})\end{array}$} \\
\hline & Median & IQR & Range & Median & IQR & Range & Median & IQR & Range & \\
\hline $\begin{array}{l}\text { Serum } \\
\text { Procalciton }\end{array}$ & $2220.9 *$ & $\begin{array}{c}2139- \\
2470.5\end{array}$ & $\begin{array}{c}1057.2- \\
2733\end{array}$ & $2679 *$ & $\begin{array}{l}2152.8- \\
2671.7\end{array}$ & $\begin{array}{c}1047.5- \\
3525\end{array}$ & 1696.9 & $\begin{array}{c}1465.3- \\
1924.1\end{array}$ & $\begin{array}{c}645.9- \\
2201\end{array}$ & $\begin{array}{c}32.6 \\
(<0.001, \mathrm{HS})\end{array}$ \\
\hline
\end{tabular}

in $(\mathbf{p g} / \mathbf{m l})$

*Significant in comparison with the controls

\begin{tabular}{|c|c|c|}
\hline $\begin{array}{l}\mathbf{P}_{1} \\
\text { (Control-stable) }\end{array}$ & $\begin{array}{l}\mathbf{P}_{2} \text { (Control- } \\
\text { Exacerbation) }\end{array}$ & $P_{3}$ (stable-exacerbation) \\
\hline$<0.001$ & $<0.001$ & 0.29 \\
\hline
\end{tabular}

procalcitonin showed an overall significant difference between study groups (P-value $<0.001)$. it was significantly lower in control group $(1696.9 \mathrm{pg} / \mathrm{ml})$ than stable $(2220.9 \mathrm{pg} / \mathrm{ml})$ and exacerbation group $(2679 \mathrm{pg} / \mathrm{ml})$. Also, it was significantly higher in the exacerbation group $(2679 \mathrm{pg} / \mathrm{ml})$ than the stable group $(2220.9 \mathrm{pg} / \mathrm{ml})$.

Table (3) Correlation between serum procalcitonin level and the studied variables among the stable COPD patients.

\begin{tabular}{lcc}
\hline With & \multicolumn{2}{c}{ Stable COPD patients } \\
& rho & P \\
\hline Age & 0.140 & 0.46 \\
Smoking index & 0.157 & 0.54 \\
Grades & 0.598 & $<0.001(\mathrm{HS})$ \\
FVC\% & -0.405 & $0.027(\mathrm{~S})$ \\
FEV1\% & -0.363 & $0.048(\mathrm{~S})$ \\
FEV1/FVC ratio & -0.401 & $0.28 \quad)$ \\
\hline
\end{tabular}

In this table, serum procalcitonin showed a significant positive correlation with COPD grade $(\mathrm{r}=0.598 \& \mathrm{P}<$ $0.001)$. In contrast, it showed significant negative correlations with FVC $(r=-0.405 \& P=0.027)$, FEV1 $(r=-0.363 \&$ $\mathrm{P}=0.048)$, and FEV1/FVC ratio $(\mathrm{r}=-0.401 \& \mathrm{P}=0.028)$. 


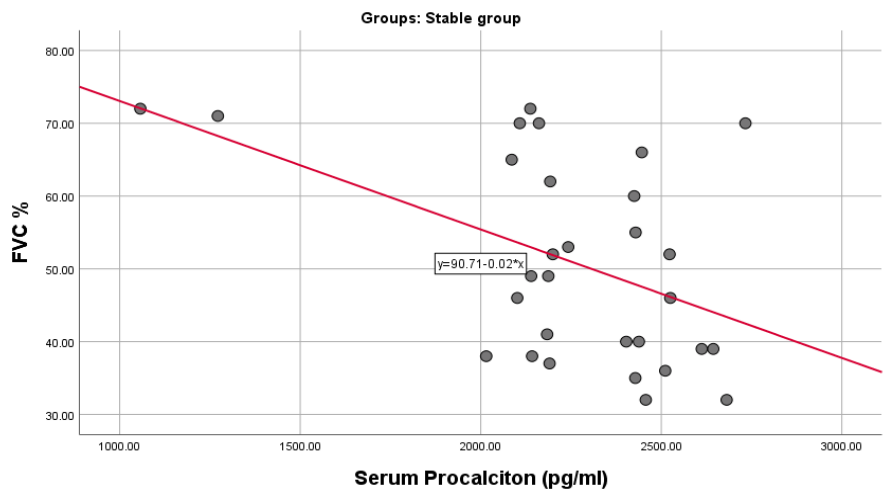

Fig. (3) Scatter graph showing a significant negative correlation between procalcitonin and FVC\% in stable COPD patients, the regression equation is also shown.

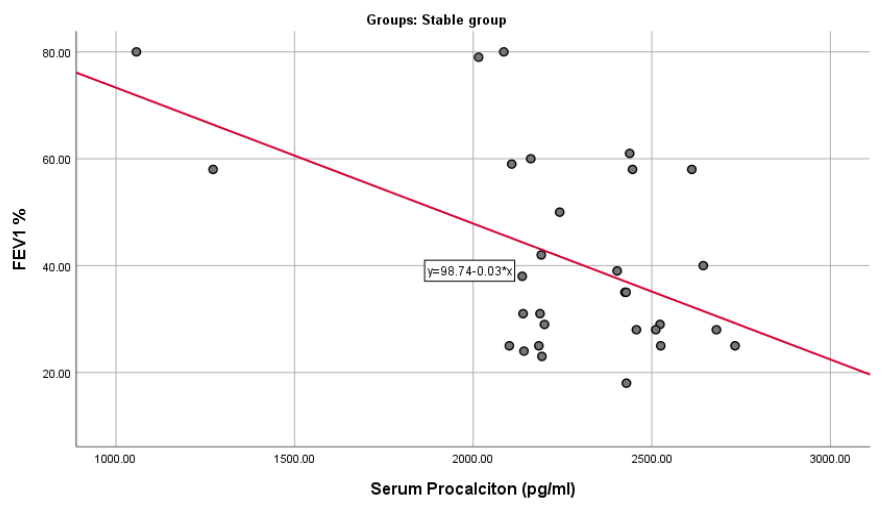

Fig. (4) Scatter graph showing a significant negative correlation between procalcitonin and FEV-1\% in stable COPD patients, the regression equation is also shown.

Table (4) Correlation between serum procalcitonin level and the studied variables among the COPD patients in the exacerbation.

\begin{tabular}{lcc}
\hline With & \multicolumn{2}{c}{$\begin{array}{c}\text { Exacerbation group } \\
(\mathbf{N}=30)\end{array}$} \\
& rho & P \\
\hline Age & 0.327 & 0.078 \\
Smoking index & 0.260 & 0.35 \\
Degree of severity & 0.812 & $<0.001(\mathrm{HS})$ \\
\hline
\end{tabular}

In this table, serum procalcitonin showed a significant positive correlation with degree of severity $(\mathrm{r}=0.812 \& \mathrm{P}$ value $<0.001$ ).

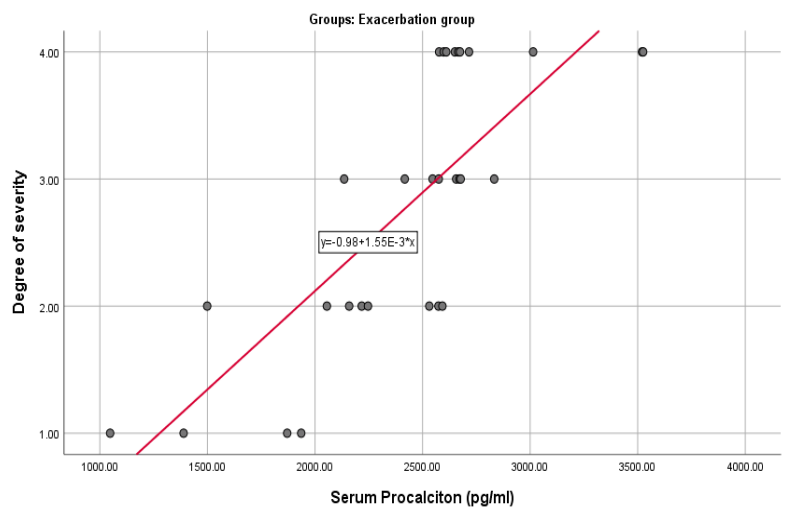

Fig. (5) Scatter graph showing a significant positive correlation between procalcitonin and degree of severity of disease in COPD patients in exacerbation, the regression equation is also shown. 


\section{Discussion}

In our research, there were no significant variations in age, BMI, gender, or smoking habits among the three groups. The mean age in the Stable group was 59.79.3 years, the mean age in the Exacerbation group was 63.211.3 years, and the mean age in the Control group was 587.7 years $(\mathrm{P}$-value $=$ $0.16)$. Table $(1,2)$ and Figure $(1,2$,

Males comprised 83.3 percent of the patients in the stable group, 73.3 percent of the patients in the exacerbation group, and 65.0 percent of the patients in the control group $(\mathrm{P}$-value $=0.33)$.

Table 1 and Figure 1 are available here.

A comparable research found that 80 individuals with stable COPD and 80 patients with AECOPD were included in the trial. When it comes to age, stable COPD patients were aged (57.08 yrs) and AECOPD patients (56.68 yrs), however there was no statistically significant difference in age between the two groups $(P=0.79)$. However, there was no statistically significant difference in the BMI of patients with acute exacerbation of COPD compared to the stable group $(\mathrm{P}=0.13)$. Males comprised the majority of patients in both groups. In $97 \%$ of patients, the most common symptoms were dyspnea and cough. [6].

According to another research, the average age of those with COPD was 56.22 years old, with an 11-year variation. A large majority of them were guys (91 percent ). COPD had a greater impact on men than on women. The 51-65-year-old age bracket was also more often impacted by COPD [7].

There was a statistically significant difference in procalcitonin levels across the research groups $(\mathrm{P}-$ value 0.001$)$. Stable $(2220.9 \mathrm{pg} / \mathrm{ml})$ and exacerbation $(2679 \mathrm{pg} / \mathrm{ml})$ groups had higher levels, whereas the control group had considerably lower levels (1696.9 $\mathrm{pg} / \mathrm{ml})$. Compared to the control group $(2220.9 \mathrm{pg} / \mathrm{ml})$, it was considerably greater in the exacerbation group (2679 pg/ml). Table(2)

According to Pandey and his colleagues, PCT levels were considerably higher in the AECOPD group $(1.31 \mathrm{ng} / \mathrm{ml})$ than in the stable COPD group $(0.1$ $\mathrm{ng} / \mathrm{ml}$ ). According to another research, PCT levels in the AECOPD ranged from $0.272-0.586 \mathrm{ng} / \mathrm{ml}$ in the AECOPD group and $0.066-0.027 \mathrm{ng} / \mathrm{ml}$ in the nonexacerbation group with a $\mathrm{P}$ value of 0.001 . Based on the data, the $0.085 \mathrm{ng} / \mathrm{ml}$ cut point for distinguishing between the AECOPD and the stable groups has a sensitivity of $68 \%$ and a specificity of $80 \%$. According to this research, PCT levels may be used as an effective diagnostic marker for individuals with COPD, as well as for distinguishing between patients with AECOPD and those with stable COPD. [8]

This research found a strong link between COPD grades $(r=0.598$ \& P-value 0.001) and serum procalcitonin levels (FVC and FEV1/FVC ratio), as well as a significant negative correlation between these two variables. Figures $(3,4)$ in Table $(3)$

For patients with pneumonia, PCT and CRP levels were significantly greater than those of patients with exacerbation of COPD ( $\mathrm{P}$ 0.0001) in a research conducted by Lacoma et al. (Stable, AECOPD, and pneumonic patients). [9]

Another research indicated that PCT levels in the blood of individuals with COPD exacerbation were very sensitive and specific in detecting the inflammatory response. Serum PCT levels were found to be normal in the individuals with stable COPD who served as the study's control group. PCT was discovered to have a bacterial infection sensitivity and specificity of $92.6 \%$ and $97.5 \%$ respectively [10].

Significantly higher median PCT levels were reported in patients with HAP, CAP, and AECOPD than in controls in all three types of hospital-acquired pneumonia. In all groups except the HAP group, the top limit of the $95 \%$ confidence interval was 0.5 $\mathrm{ng} / \mathrm{mL}$. The control group did not have PCT levels above the prescribed cut-off level [11].

A substantial positive connection $(r=0.812 \&$ Pvalue 0.001 ) was found between serum procalcitonin levels and the severity of the exacerbation group. Table (4) and Figure (5) are included in this section

In a case-control research, the mean level of PCT (0.19 0.02) was found in both the AECOPD (case group) and stable (control group) groups. Compared to the control group, it was considerably greater in cases $(P=0.0001)$. For all phases of COPD the same PCT level was used. Depending on the type and severity of AECOPD, there were significant changes in the mean PCT levels. While PCT levels were much lower in patients getting non-invasive positive pressure ventilation (NPV) than in those not receiving NPPV (P $=0.0001)$, this difference was not statistically significant. The PCT cut-off value of $0.10 \mathrm{ng} / \mathrm{ml}$ was shown to be a marker of NPPV in humans. Patients with AECOPD had PCT levels that were greater than those with stable COPD, as was predicted. This is particularly true in patients with severe AECOPD and those who are taking NPPV [12].

The amount of procalcitonin (1.01 (1-1.03), $\mathrm{P}=$ 0.018 ) was shown to be related to an increased risk of ICU death in another investigation. A lower risk of ICU mortality was seen when noninvasive mechanical ventilation was used prior to intubation $(\mathrm{P}=0.020$, $0.34(0.14-0.84))$. There is an independent relationship between elevated procalcitonin levels and an increased risk of ICU death in patients with severe acute exacerbations of COPD [13].

\section{Conclusion}

- PCT is negatively correlated with FEV1 \% in stable COPD.

- PCT is passively correlated with severity of exacerbated COPD.

\section{References}

[1] Global Initiative for Chronic Obstructive Lung Disease, Global strategy for the diagnosis, management and prevention of chronic obstructive pulmonary disease. NHLBI/WHO 
Global Initiative for Chronic Obstructive Lung Disease (GOLD), 2021.

[2] K.Reinhart, W.Karzai and M.Meisner, "Procalcitonin as a marker of the systemic inflammatory response to infection". Intensive Care Medicine.vol.26 (9),pp.1193-200,2000.

[3] M.Meisner, Procalcitonin biochemistry and clinical diagnosis (1st ed.). Bremen: UNI-MEDVerl,2010.

[4] Ed.Carrol, APJ.Thomson, CA.Hart, Procalcitonin as a marker of sepsis. Int J Antimicrob Agents.vol.20,pp.1-9,2002.

[5] YJ.Liu, P.Du and J.Rao, Procalcitonin as a diagnostic and prognostic marker for sepsis caused by intestinal infection: A case report. Eur Rev Med Pharmacol Sci.vol.17,pp.13111313,2013.

[6] S.Pandey, R.Garg, S.Kant, A.Verma, P.Gaur, Serum procalcitonin levels in chronic obstructive pulmonary disease patients in North Indian Population. Ann Afr Med.vol.18(2),pp.103$107,2019$.

[7] A.Kanwal, A.Bashir, A.Gohier, B.Habib, Association of red blood cell indices and erythrocyte sedimentation rate in CHRONIC OBSTRUCTIVE PULMONARY DISEASE (COPD) patients. Pak Armed Forces Med J.vol.71 (2),pp.610-13,2021.
[8] H.Borsi, E.Pajohan-Nia, M D.Mal-Amir, H.Raji, Relationship between serum procalcitonin level and chronic obstructive pulmonary disease. J Family Med Prim Care.vol.8(2),pp.738740,2019.

[9] A.Lacoma, C.Prat, F.Andreo, L.Lores, J.RuizManzano, V.Ausina et al., Value of procalcitonin, C-reactive protein, and neopterin in exacerbations of chronic obstructive pulmonary disease; Int J Chron Obstruct Pulmon Dis.vol.6,pp.157-169,2011.

[10]C.Tasci, A.Balkana, N.Karadurmus, S.İnal, S.Kilic, M.Özkan, et al ., The importance of serum procalcitonin levels in patients with chronic obstructive pulmonary disease exacerbations. Turk J Med Sci.vol.38,pp.13944,2008.

[11]A.Polzin, M.Pletz, R.Erbes, M.Raffenberg, H. Mauch, S.Wagner, et al ., Procalcitonin as a diagnostic tool in lower respiratory tract infections and tuberculosis; European Respiratory Journal.vol.21,pp.939-943,2003.

[12] AC.Pazarli, HI.Koseoglu, S.Doruk, S.Sahin, I.Etikan, S.Celikel, et al., Procalcitonin: Is it a predictor of noninvasive positive pressure ventilation necessity in acute chronic obstructive pulmonary disease exacerbation. J Res Med Sci.vol.17(11),pp.1047-51,2012.

[13]B.Rammaert, N.Verdier, B.Cavestri , S.Nseir, Procalcitonin as a prognostic factor in severe acute exacerbation of chronic obstructive pulmonary disease, 2009 . 